\title{
Primary care assessment from a male population perspective
}

\author{
A avaliação da atenção primária a saúde na perspectiva da população masculina \\ La evaluación de atención primaria a la salud en la perspectiva de la población masculina
}

\section{Abiúde Nadabe e Silva', Simone Albino da Silva", Ana Roberta Vilarouca da Silva'"', Telma Maria Evangelista de Araújo ${ }^{\text {Iv }}$, Cristiana Brasil Almeida Rebouças ${ }^{v}$, Lídya Tolstenko Nogueiral}

'Universidade Federal do Piauí, Postgraduate Program in Nursing. Teresina, Piauí, Brazil.

"Universidade Federal de Alfenas, Department of Nursing. Alfenas, Minas Gerais, Brazil.

II' Universidade Federal do Piauí, Department of Sciences and Health. Picos, Piauí, Brazil.

" Universidade Federal do Piauí, Center for Health Sciences, Department of Nursing. Teresina, Piauí, Brazil.

${ }^{v}$ Universidade Federal do Ceará, Department of Nursing. Fortaleza, Ceará, Brazil.

How to cite this article:

Silva AN, Silva SA, Silva ARV, Araújo TME, Rebouças CBA, Nogueira LT. Primary care assessment from a male population perspective. Rev Bras Enferm [Internet]. 2018;71(2):236-43. DOI: http://dx.doi.org/10.1590/0034-7167-2016-0651

Submission: 02-04-2017

Approval: 03-13-2017

\section{ABSTRACT}

Objective: to evaluate the quality of primary health care from the perspective of the male population. Method: a cross-sectional descriptive-evaluative study conducted at the family health units of Teresina, Piauí, Brazil, with the male population being interviewed through the Primary Care Assessment Tool (PCAT). Results: 301 participants with mean age of 51.34 years, married, incomplete elementary school and monthly income between one and two minimum wages. The evaluation was positive for the following care domains: utilization, information system and longitudinality. The features access, comprehensiveness of care, service available and service provided, family centeredness and community orientation obtained a negative evaluation. Conclusion: the features of primary care are unsatisfactory, indicating the need to expand access to services offered and to qualify care for male users.

Descriptors: Health Services Evaluation; Primary Health Care; Men's Health; Community Health Nursing; Public Health.

\section{RESUMO}

Objetivo: avaliar a qualidade da atenção primaria a saúde na perspectiva da população masculina. Método: estudo descritivo, avaliativo, com delineamento transversal, realizado em unidades básicas de saúde da família, de Teresina, Piauí, Brasil, com a população masculina entrevistada seguindo o Primary Care Assessment Tool. Resultados: 301 participantes com média de idade de 51,34 anos, casados, ensino fundamental incompleto e renda mensal entre um e dois salários mínimos. A avaliação foi positiva para os atributos: Utilização, Sistema de Informações e Longitudinalidade. Os atributos Acessibilidade, Integração de Cuidados, Serviços Disponíveis e Prestados, Orientação Familiar e Comunitária obtiveram avaliação negativa. Conclusão: os atributos da atenção primária estão insatisfatórios, indicando a necessidade de ampliar o acesso aos serviços ofertados e de qualificar o cuidado aos usuários masculinos.

Descritores: Avaliação de Serviços de Saúde; Atenção Primária a Saúde; Saúde do Homem; Enfermagem em Saúde Comunitária; Saúde Pública.

\section{RESUMEN}

Objetivo: evaluar la cualidad de atención primaria a la salud en la perspectiva de la población masculina. Método: estudio descriptivo, evaluativo, con delineamiento transversal, realizado en unidades básicas de salud de la familia, de Teresina, Piauí, Brasil, con la población masculina entrevistada siguiendo el Primary Care Assessment Tool. Resultados: 301 participantes con un promedio de edad de 51,34 años, casados, enseñanza básica incompleta y renta mensual entre uno y dos salarios mínimos. la evaluación fue positiva para los atributos: Utilización, Sistema de Informaciones y Longitud. Los atributos Accesibilidad, Integración de Cuidados, Servicios Disponibles y Prestados, Orientación Familiar y Comunitaria obtuvieron evaluación 
negativa. Conclusión: los atributos de atención primaria están insatisfactorios, indicando la necesidad de ampliar el acceso a los servicios ofertados y de cualificar el cuidado a los usuarios masculinos.

Descriptores: Evaluación de Servicios de Salud; Atención Primaria a la Salud; Salud del Hombre; Enfermería en Salud Comunitaria; Salud Pública.

\section{CORRESPONDING AUTHOR Simone Albino da Silva E-mail: simonealbino76@hotmail.com}

\section{INTRODUCTION}

Primary Health Care (PHC) is an approach that underpins and determines the work of the other levels of health care. It addresses the most common problems in the population, providing prevention, cure and rehabilitation services to increase health and wellbeing, and organizing and rationalizes the use of resources for health promotion, maintenance and improvement ${ }^{(1)}$.

In Brazil, the Family Health Strategy (FHP) is a priority for the expansion and consolidation of PHC, as it favors the reorientation of the work process with the potential to deepen its principles and guidelines, to increase the resolvability and impact on the health situation of individuals and communities, besides providing an important cost-effectiveness ratio( ${ }^{(2)}$.

Despite these characteristics, the FHS teams have not effectively produced actions involving care for men, mainly adults( ${ }^{(3)}$. Over the decades, the health needs of Brazilian men have been neglected by the absence of specific preventive actions for the public, with the favoring of groups such as children, women and the elderly, through public health policies, and improving the quality of life for these population segments.

In the routine of PHC services, the presence of more women than men is evident. Whereas men usually seek care when they experience some acute or chronic illness, the female population seeks preventive and educational activities focused on women's health. The fact that men use PHC services less and the overload of specialized attention thereby arising, leads to often-avoidable costs; the high rates of male morbidity and mortality are public health problems, since they reduce the life expectancy of this group.

At least two themes pose challenges to the public health system: actions encouraging men to seek PHC services and their adaptation to male demands ${ }^{(4)}$. Listening to male users who seek health services can be a means to achieve the necessary adjustment to their needs ${ }^{(4)}$ and to subsidize the shared decision-making process in order to review professional practices, reorganize the work process, re-allocate resources, and redefine objectives consistent with the established health project ${ }^{(5)}$. Thus, when conducting evaluation studies, it is possible to know the perception the service users about the health care models, practices and management that have been implemented in the $\mathrm{PHC}^{(6)}$.

Given this scenario, the objective of this study was to evaluate the primary health care, from the perspective of male users of the Family Health Strategy.

\section{METHOD}

\section{Ethical aspects}

The study was approved by the Standing Committee on Ethics in Research with Human Beings, Federal University of Piauí.
Participants signed the informed consent term, in accordance with Resolution 466/2012 of the National Health Council(7).

\section{Study design, place and period}

This is a cross-sectional descriptive-evaluative study conducted in Basic Health Units (BHUs) located in the urban area of Teresina, capital of the state of Piauí, Brazil, whose model of care is the Family Health Strategy (FHS). The data collection took place from January to July 2015, in the premises of the selected UBS, through interviews conducted individually with male users, without the presence of FHS staff members.

\section{Sample and inclusion and exclusion criteria}

Study participants were selected by means of two-stage conglomerate sampling. In the first stage, $12 \mathrm{BHU}$ s were selected by simple random sampling, with probability proportional to the number of units in each Health Region, having as eligibility criteria to present at least four ESF teams in activity. In the second step, for the choice of study participants, the sample was initially calculated considering the tolerable error of $6 \%$, according to the following formula ${ }^{(8)}: \mathrm{n}=\mathrm{N} \cdot \mathrm{no} / \mathrm{N}+$ no, where: $\mathrm{n}=$ sample size; $N$ = population size; $n o=$ first approximation to sample size (no $=1 / \mathrm{E} 2$ ); $\mathrm{E}=$ tolerable error. A sample of 227 male users was obtained, plus $10 \%$ to cover losses. Participants were recruited for the survey as they appeared in the selected BHUs, after a brief screening to verify compliance with the inclusion criteria: age 18 or older, previously attended at least once in the last two years for any ESF team from Teresina. The exclusion criterion was to present health problems that impeded the understanding of the research instruments.

\section{Study protocol}

The interview script consisted of the identification of the social and demographic profile and the Primary Care Assessment Tool (PCA Tool), which evaluates the degree of orientation to PHC through attributes called 'essential' and 'derived $^{\prime(9)}$. The essential attributes are so called because a basic care service, directed to the general population, can only be deemed as a PHC provider if they are present. Derived attributes quality the primary health actions, enhancing their integration with individuals and communities ${ }^{(9)}$.

The answers for each of the 88 items of the instrument allow the following options: 'certainly yes' (value $=4$ ), 'probably yes' (value $=3$ ), 'probably not' (value $=1$ ) and 'I do not know / do not remember' (value $=9$ ). The average score of each component was calculated by adding the value of the items divided by the number of items ${ }^{(9)}$.

The essential score was obtained by the simple average between the components of the essential attributes and the degree 
of affiliation of the user with the health service, and the derived score was obtained by the simple average among the components of the derived attributes. Already the general score, by the average between the components of the essential attributes the derived attributes and the degree of affiliation. The value of the scores (E) was standardized for a scale ranging from 0 to 10 , done by applying the score in the formula: $E=[$ (score- 1$) \times 10]$ $/ 3^{(10)}$. Services with a quality score of 6.6 or higher were considered strongly oriented to the quality of $\mathrm{PHC}$, while values lower than 6.6 were considered low quality ${ }^{(11)}$.

The degree of affiliation to the health service / health professional, that is, how much the user recognizes the service or the health professional as a reference for health care, corresponds to the first part of PCA Tool and was calculated using the scoring algorithm from 1 to $4^{(9)}$.

We considered the hypothesis that the general score is associated to the motives and frequency of the demand for care in the Basic Health Unit and also to the variables Longitudinality and Coordination (information systems).

\section{Analysis of results and statistics}

The answers were typed in a database prepared in the Microsoft Excel software by double entry, and analyzed in the software Statistical Package for the Social Sciences (SPSS), version 22, in which both the descriptive analysis of variables and the test were performed Pearson-squared test to verify association between qualitative variables. The significance level adopted for the tests was $5 \%$ and the confidence interval was $95 \%$.

\section{RESULTS}

A total of 301 participants were interviewed. The mean age was 51.34 years, the predominant age group was 41 to 59 years old $(48.17 \%)$, married or in a stable union (72.09\%), brown (48.17\%), incomplete primary education $(41.21 \%)$, paid occupation $(57.81 \%)$, working in the production of industrial goods and services or repair and maintenance services $(42.52 \%)$ and monthly income one and two minimum wages (32.56\%), and in 2015, in Brazil, the minimum wage was $\mathrm{R} \$ 778.00$.

Regarding the degree of affiliation, $58.83 \%$ indicated the UBS doctor as a reference for their care; $28.99 \%$ indicated UBS and $0.42 \%$, the unit nurse. Of the participants in this study, $20.93 \%$ identified other health services as the main reference for their care: the urgency of a public hospital or private clinic.

Table 1 shows the attributes scores of the APS and its components. A high $(\geq 6.6)$ score was observed for the components Utilization (7.96) and Information System (8.26) and for the attributes Longitudinality (6.82) and Coordination (7.31). It should be noted that the other attributes and components obtained low mean scores $(<6.6)$. Thus, all scores were below satisfactory: essential score - 5.75; derived score -4.94 and overall score -5.59 .
Table 2 shows that enrolment in the Registration and Monitoring of Hypertensive and Diabetic (Hiperdia) was the major reason for greater demand for care in the Health Units $(41.20 \%)$, followed by routine visit (17.61\%) at the time of data, collection.

The frequency at which the participants sought care in the UBS had close percentages for: sporadically $(20.60 \%)$, every 2 months (19.93\%) and every 6 months (19.93\%), as shown in Table 3.

Table 4 shows that the reason for the demand for care in the health units was not associated with the overall PHC score $(p=0.089)$. Also, the frequency of the demand for care was associated with the scores $(p<0.001)$ because the higher the regularity of the attendance to the $\mathrm{BHU}$, the higher the percentage of high scores attributed by men.

When associating scores lower than 6.6 and greater than or equal to 6.6 with age for all features, only for Longitudinality and Information System the age group was significantly associated with the feature score $(p<0,05)$ (Table 5).

In relation to Longitudinality, the greater the age of the participants, the better the evaluation, since in the 18-24 age group the percentage with a score $\geq 6.6$ was $41.18 \%$, and over 60 years this percentage was $70 \%$. The Information System was also better evaluated by the participants with higher age: in the 18-24 age group the percentage with a score $\geq 6.6$ was $82.35 \%$, and over 60 years this percentage was $94.44 \%$.

Table 1 - Minimum, maximum and average scores with standard deviation and coefficient of variation (CV) of attributes and components of Primary Health Care from the perspective of male users of the Family Health Strategy, Teresina, Piauí, Brazil, 2015

\begin{tabular}{lcccccc} 
Attributes / components & $\mathbf{n}$ & Minimum & Maximum & Average & SD* & CV**(\%) \\
\hline $\begin{array}{l}\text { Degree of affiliation } \\
\text { Essential features }\end{array}$ & 269 & 0.00 & 10.00 & 6.28 & 3.03 & 48.23 \\
First contact access & & & & & & \\
Utilization & 301 & 0.14 & 10.00 & 5.32 & 1.66 & 31.28 \\
Accessibility & 300 & 0.00 & 7.78 & 2.65 & 1.63 & 61.48 \\
Longitudinality & 301 & 0.00 & 10.00 & 6.82 & 2.01 & 29.39 \\
Coordination & & 0.00 & 10.00 & 7.31 & 1.92 & 26.29 \\
Care integration & 205 & 0.00 & 10.00 & 5.68 & 2.46 & 43.35 \\
Information system & 300 & 0.00 & 10.00 & 8.26 & 1.89 & 22.90 \\
Comprehensiveness & & 0.00 & 10.00 & 4.14 & 1.93 & 46.62 \\
Available services & 262 & 0.15 & 10.00 & 4.73 & 1.79 & 37.92 \\
Services provided & 300 & 0.00 & 10.00 & 3.77 & 2.41 & 63.97 \\
Essential score & & 0.95 & 9.11 & 5.75 & 1.39 & 24.17 \\
Attributes derived & & & & & & \\
Family counseling & 301 & 0.00 & 10.00 & 4.65 & 3.12 & 67.12 \\
Community orientation & 290 & 0.00 & 10.00 & 5.31 & 2.70 & 50.85 \\
Derived score & & 0.00 & 10.00 & 4.94 & 2.50 & 50.61 \\
Overall score & & 0.71 & 9.29 & 5.59 & 1.48 & 26.48 \\
\hline & & & & & &
\end{tabular}

Note: * Standard deviation; **Coefficient of variation. 
Table 2 - Reason for demand for care in the Basic Health Units, Teresina, Piauí, Brazil, July, 2015 ( $N=301)$

\begin{tabular}{lcc}
\hline Reason & $\mathbf{n}$ & $\mathbf{\%}$ \\
\hline Hiperdia service & 124 & 41.20 \\
Routinevisit & 53 & 17.61 \\
Specialized appointments / exams & 36 & 11.96 \\
Laboratory exams & 27 & 8.97 \\
Urgent care & 26 & 8.64 \\
Dental treatment & 11 & 3.65 \\
Others & 24 & 7.97 \\
\hline
\end{tabular}

Table 3 - Frequency at which men seek care in the Basic Health Units, Teresina, Piauí, Brazil, July, 2015 ( $N=301)$

\begin{tabular}{lll}
\hline Frequency & $\mathbf{n}$ & \% \\
\hline Once a month & 46 & 15.28 \\
Every 2 months & 60 & 19.93 \\
Every 3 months & 39 & 12.96 \\
Every 6 months & 60 & 19.93 \\
Annually & 34 & 11.30 \\
Sporadically & 62 & 20.60 \\
\hline
\end{tabular}

Table 4 - Association between the reason and the frequency of the demand for care in the Basic Health Units with the high and low general Primary Health Care score, Teresina, Piauí, Brazil, July, 2015 ( $\mathrm{N}=301)$

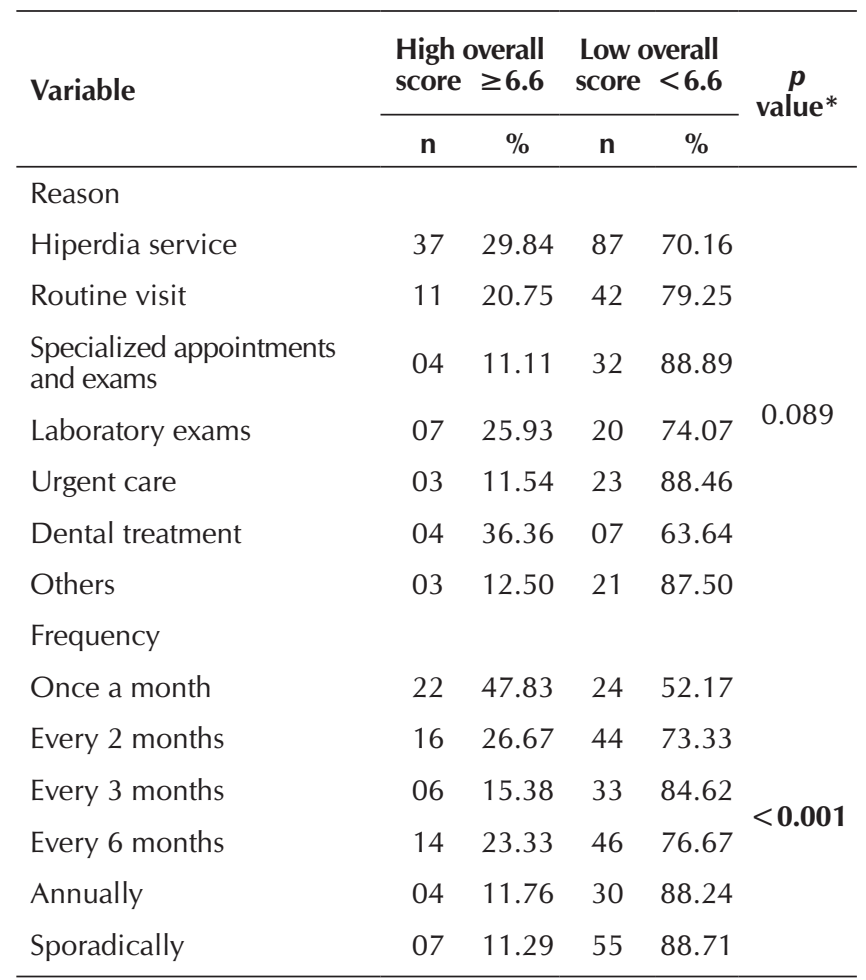

Note: * Significance of Pearson's Chi-Square Test.
Table 5 - Distribution of features classified as high and low primary health care score, according to the age range, Teresina, Piauí, Brazil, July

\begin{tabular}{ccccc}
\hline \multirow{2}{*}{ Variable } & $\begin{array}{c}\text { High score } \\
\geq 6.6\end{array}$ & $\begin{array}{c}\text { Low score } \\
<6.6\end{array}$ & $\begin{array}{c}p \\
\text { value* }\end{array}$ \\
\cline { 2 - 5 } & $\mathrm{n}$ & $\%$ & $\mathrm{n}$ & $\%$ \\
\hline
\end{tabular}

$\begin{array}{llllll}\text { Longitudinality (301) } & & & & \\ \text { 18-24 y.o. } & 07 & 41.18 & 10 & 58.82 & \\ 25-40 \text { y.o. } & 18 & 36.73 & 31 & 63.27 \\ 41-59 \text { y.o. } & 94 & 64.83 & 51 & 35.17 & <\mathbf{0 . 0 0 1} \\ 60 \text { y.o.or over } & 63 & 70.00 & 27 & 30.00\end{array}$

Coordination - Information system (300)

$\begin{array}{lccccc}\text { 18-24 y.o. } & 14 & 82.35 & 03 & 17.65 & \\ 25-40 \text { y.o. } & 39 & 79.59 & 10 & 20.41 & \\ 41-59 \text { y.o. } & 129 & 89.58 & 15 & 10.42 & 0.047 \\ 60 \text { y.o. or over } & 85 & 94.44 & 05 & 5.56 & \end{array}$

Note: * Significance of the Pearson Chi-Square Test (for all participants).

\section{DISCUSSION}

Some studies conducted in Brazil have found a low percentage of male participants in PHC compared to women ${ }^{(12-14)}$. The shortcomings in the Brazilian scientific publications on the exclusive or predominant perspective of the male population on $\mathrm{PHC}$ are highlighted. On the one hand, the lower demand of men in the FHT may be due to a greater link with work; on the other, because the PHC service does not prioritize these users ${ }^{(15)}$.

In this sense, a study with men in Minas Gerais, Brazil, found participants in the 51-59 age group (37.3\%), followed by 41 to 50 years $(27.6 \%)^{(16)}$. Another study, carried out in João Pessoa (PB), identified a majority of men aged 60 years or older attending the $\mathrm{FHU}^{(17)}$, similar findings to this study. The largest portion of the male population that seeks care in the FHT is older than 40 years. Hence, there is a the need for actions that include men from the youth, in order to develop activities directed to the promotion of health, prevention of diseases and injuries, carried out inside and outside the unit, prioritizing the work and study spaces. Regarding the marital status, the survey carried out in MG, with 527 adults of both sexes, identified predominance of married individuals ${ }^{(13)}$, which is also in line with this research. The sample is also characterized by low level of schooling, a result that converges with the literature ${ }^{(12,16-17)}$, in addition to low monthly income $\mathrm{i}^{(12,17)}$.

Regarding the degree of affiliation identified in this study, it is observed that men still see, first and foremost, the physician's role as a care provider, seeking curative services, and are unaware of the preventive health and nursing attributions in $\mathrm{PHC}^{(18)}$. However, another study has shown that, even among women, the demand for nurses is very low $(5.5 \%)$, demonstrating the non-recognition by the population of the identity of the professional wearing white in the health units, due to lack of 
presentation during the nursing consultation or by the non-development of actions that guarantee visibility to the nurse ${ }^{(19)}$.

As far as referral for care being the urgency of a public hospital or private clinic, the data were higher than those of another study, which found that $10.07 \%$ of the adult users surveyed felt connected to the hospital, emergency room or emergency room service $^{(11)}$. In this sense, when analyzing the difficulties of access of men to PHC in Macaíba, Rio Grande do Norte (Brazil), a study identified that $84 \%$ preferred hospitals and emergency rooms, $8 \%$ sought pharmacies and another $8 \%$, medical clinics ${ }^{(20)}$. In addition, in situations considered to be risk-free, most men seek alternative resources, such as pharmacy and self-medication, which they say avoid queuing and waiting for medical attention ${ }^{(21)}$.

In analyzing PHC quality, the first attribute assessed was First Contact Access, subdivided into two components: Utilization, which refers to the extent and type of use of health services; and Accessibility, which involves the location of the health unit close to the population which it attends, the hours and days when it is open to provide services, the degree of tolerance for unplanned consultations, and how much the population perceives the convenience of these aspects of accessibility ${ }^{(1)}$.

The feature Utilization obtained a high score, evidencing that users recognize PCS as the main gateway to Brazil's health services (SUS), a finding that agreed to the results of other studies ${ }^{(5,13,19,22-23)}$. The demand for the PHC unit is clearly recognized as necessary for access to a specialist consultation $^{(14)}$, since the most frequent access to specialized care is through referrals from $\mathrm{PHC}$ services ${ }^{(12)}$.

Although access is a fundamental characteristic of $\mathrm{PHC}$ services, the Accessibility component had a low score, a result similar to that identified in other studies ${ }^{(5,13,19,22-23)}$. In this study, the low score attributed to Accessibility may be related to the fact that the FHS teams participating in the survey only work on business days and business hours (7am to 5pm), and do not work in the evenings, weekends or without previous consultation appointments, except for minor emergencies. In this research, the largest number of interviews was conducted from 6:00 am to 8:00 am, while the participants waited for patients, since later most of them had to go to work.

The Longitudinality attribute had a high average score, converging with some studies ${ }^{(13,22)}$ and diverging from others ${ }^{(19,23)}$, which found a low score. Longitudinality presupposes the existence of a regular source of attention and its use over time ${ }^{(1)}$, in addition to identifying the relationship between the user and the professional ${ }^{(5)}$. The result of this attribute is in line with the good performance of the Affiliation Degree and First Contact Access in the Utilization dimension, which is in favor of the team, which will not have difficulty approaching male users for involvement in the FHS actions and services. However, one study ${ }^{(24)}$ states that PHC workers must know their assigned population and consider that, in order to build a bond, it is necessary to recognize the user as a subject who speaks, judges and desires.

The Coordination feature requires continuity - either by professionals, or by means of medical records -, problem recognition and referrals, when necessary, in order to guarantee health care integration at all levels ${ }^{(1)}$. Its component Care Integration had a low average score, in agreement to that identified by other studies ${ }^{(13,19,22-23)}$. On the other hand, the Information System component obtained a high score. Because it refers to the local organization of the $\mathrm{PHC}$, it presents a similar result to that found by some surveys ${ }^{(19,22)}$, but different from others that observed a low score ${ }^{(13,23)}$.

Hence, it can be said that the integration of the different health care levels is fragile, which compromises the strengthening of PHC, networking and the consolidation of the health system $(\mathrm{S} U S)^{(24)}$. It is reiterated that the integration among services of different degrees of complexity, in order to allow access to both PHC and specialized and highly technological complexity, is also a fundamental responsibility of SUS ${ }^{(14)}$.

Integrality refers to the set of services available and provided by primary care to users, including promotion, prevention, cure and rehabilitation actions, in order to guarantee comprehensive care $^{(1)}$. The Available Services component had a low average score, a result that converged with the literature on the topic ${ }^{(13,19,22-23)}$; it refers to the list of services and / or guidelines that users, their family and others who use the FHS may need at some point ${ }^{(9)}$. It should be noted that the services recognized as available show a very traditional practice in the FHU units, with consolidated preventive actions focused on women's and children's health, and that do not provide space for health promotion and for the diversity of needs of the population ${ }^{(13)}$.

The Services Provided component also had a low average score, a finding similar to that found in other studies ${ }^{(13,19,22-23)}$, expressing that there are few actions aimed at preventing injuries and promoting health in the experience of different FHS users. The evaluation of the Services Provided is directed at the actions and services used by the user or by someone in the family at the FHS unit ${ }^{(13)}$. Despite the importance of Integrality to guarantee the effectiveness of $\mathrm{PHC}$, the components of this attribute had a lower result than that expected.

Although family centeredness is key to guarantee quality care, this study showed that the Family Orientation attribute obtained an average score below the established reference, coinciding with the results of surveys conducted in other Brazilian cities, in the perception of different users ${ }^{(13,22-23)}$. This feature is consolidated when the scope of Integrality provides a basis for the consideration of patients within their environments, when the needs assessment considers the family context and its exposure to health threats, and when Care Coordination faces limited family resources ${ }^{(1)}$.

In assessing Community Orientation, the men interviewed attributed a low score to that feature, similar to that of other studies $^{(13,19,22-23)}$. The primary care service has to know the social context in whichusers are inserted to understanding their needs, considering that the characteristics of the environment have repercussions on the health condition and are evidenced in this feature ${ }^{(1)}$.

One of the working strategies to know the community is the home visit, which must be performed by all health professionals ${ }^{(25)}$. However, when asked if someone from PHC performs home visits, a number of men answered 'certainly, yes', but referring only to the community health agent. Others have reported that the team with doctor and nurse only visits homes where people are bedridden. 
Thus, it was verified that the majority of APS attributes had a score below the ideal, which indicates a poor quality of PHC developed in the services surveyed. This result endorses the existing literature: Iow essential score ${ }^{(13,22-23)}$, derivative $\mathrm{e}^{(23)}$ and general $^{(13,22-23)}$, showing that the FHT, in different places and from the perspective of different social actors, still does not have the necessary guidance on the APS attributes.

Thus, it was verified that the majority of PHC qualifiers presented a score below the ideal, which indicates its poor quality in the services surveyed. This result endorses the existing literature: low essential ${ }^{(13,22-23)}$, derivative ${ }^{(23)}$ and general ${ }^{(13,22-23)}$ scores, showing that the FHS, in different places and from the perspective of different social actors, still does not have the necessary orientation to the PHC features.

In relation to the fact that the Hiperdia service is the most frequent and the main reason for men's search for care in the units surveyed, that reinforces that the demand for services for the treatment of acute and chronic diseases still predominates in this part of the population. Other studies have pointed to the curative culture, indicating that hypertension is the main reason for the male population looking for $\mathrm{BHUs}(25 \%)$, followed by pain $(20 \%)^{(17)}$. Among individuals seeking prevention $(38.5 \%)$, there is a preference for private health services to the disadvantage of the FHU units ${ }^{(26)}$.

According to PHC professionals, the main complaints of men are related to cardiovascular diseases, hypertension, diabetes and sexuality issues ${ }^{(27)}$. Also, this demand can be induced by the type of activities available and directed to men, punctual and focused on clinical assistential actions ${ }^{(27)}$.

This study emphasizes that the large number of hypertensive and / or diabetic patients who attend PHC more regularly because Hiperdia is a ministerial program focused on the specific and regular care of this group of people, with a free supply of the medicines required for the treatment, thus indicating that the male user's presence in the health service may be due to the existence of chronic diseases. This characteristic of higher frequency at the service was associated with the general score $(p<0.001)$ because the higher the frequency, the higher the percentage of high scores attributed by men; and the lower the regularity of the search for PHC, the higher the percentage of low scores.

This result is confirmed by findings in the literature, in which services identified as having a high degree of orientation to PHC have populations that are significantly different in terms of health status: the longer the disease (10.9 years), the greater the presence of diabetes-related complications (73.9\%), and the higher frequency of use of health services (8.5 visits / year) ${ }^{(28)}$.

Likewise, caregivers of children under two years old, assisted by the FHS in Montes Claros (MG), who performed more than ten visits, were ascribed better $\operatorname{scores}^{(29-30)}$. Therefore, it should be noted that the higher the frequency at which users are treated in PHC, the better evaluated is the health service, possibly because they build a link with the ESF team.

For the men participating in this study, the older the participants, the better the evaluation of the Longitudinality attribute. Although there was no statistical association, men over 60 years of age positively evaluated the Information System component of the Coordination attribute, which obtained a high score. In the literature, there is no consensus about this result, since, contrary to this, a study showed that the younger users (mean of 28.84 years) generally classified the PSA with high scores and those with the highest age (mean of 32.68 years), with low score, with the statistical significance $(p<0.01)^{(19)}$. Another study indicates that the high score evaluation of the feature shows favorable conditions for the existence of registration and availability of the information for the development of the Care Coordination and Longitudinality ${ }^{(31)}$, which reinforces the positivity of this result in terms of the $\mathrm{PHC}$ quality, especially to users with chronic diseases.

In view of the results, the need to develop strategies that facilitate the access of the male population to PHC services, with flexible working hours, as well as the inclusion of specific educational activities for the public, are highlighted. Priority should be given to preventing diseases and promoting health in all age groups, so as to broaden the range of actions available in the $\mathrm{PHC}$, thereby raising awareness among men about the importance of self-care, which may contribute to the reduction of morbidity and mortality rates due to preventable causes.

In addition, it is important that FHS teams include and consider the family context in meeting the needs of PHC users, especially of male users, valuing and encouraging community participation in the service restructuring process, in order to guarantee integrated and humanized service.

\section{Limitations of the study}

The research was restricted to the capital of a state in northeastern Brazil and exclusively considered the perspective of male users, who may present a more critical view of the services offered when compared to other social actors such as professionals and managers. It is worth noting that the PCA Tool does not have specific items for the male population, but it is a relevant instrument, since it considers the features inherent to PHC care and that must be worked out with this public.

\section{Contributions to the area of nursing and public health}

There is undeniable importance and contribution of $\mathrm{PHC}$ nurses performing tasks directed at several population groups reached by health programs and / or policies. Thus, in spite of institutional and socio-cultural obstacles to the adequate care of the male demand, the nurses' potential can be tapped into for the programming of extramural actions that enable and stimulate the promotion of health and preventive care.

The findings of this study therefore indicate the need for nurses to expand their scope of action, as was evident in the Integrality attribute, which obtained a score below the ideal, and actively involve the family and the community in the development of their care activities, since the Family and Community Orientation attributes also reached unsatisfactory scores. That can give visibility and recognition to their work, primarily focused on prevention and health promotion.

\section{CONCLUSION}

By and large, the APS features had a mean score below 6.6, with low essential, derivative and general scores for the APS services in Teresina, carried out through the FHS. That shows 
a fragile presence and extension of most qualifiers, which reflects the male users' unsatisfactory evaluation of PHC. Therefore, there are still many challenges to be overcome in order to implement FHT as a strategy to reorganize $\mathrm{PHC}$ in order to guarantee comprehensive and universal quality assistance to the male population that seeks care.

The results show the need to improve health care for the male population. Furthermore, we emphasize the responsibility of each federative entity in guaranteeing full and quality assistance to all SUS users, in accordance with constitutional principles and those established through public policies. We reiterates the importance of public policies not only being created but effectively implemented to ensure that their objectives are achieved and that there is indeed an improvement in the health conditions of different population groups.

We suggest the conduction of new evaluative research directed to different population and social groups, aiming to show the existing reality in different places of the country, in order to reach an expanded vision of $\mathrm{PHC}$ and contribute to the improvement of health care at the level national.

\section{REFERENCES}

1. Starfield B. Atenção primária: equilíbrio entre necessidades de saúde, serviços e tecnologia. Brasília: Unesco; 2002.

2. Brasil. Ministério da Saúde. Secretaria de Atenção à Saúde. Departamento de Atenção Básica. Política Nacional de Atenção Básica (PNAB). Série E. Legislação em Saúde [Internet]. Brasília: Ministério da Saúde, 2012 [cited 2016 Feb 8];110p. Available from: http://189.28.128.100/dab/docs/publicacoes/geral/pnab.pdf

3. Machin R, Couto MT, Silva GSN, Schraiber LB, Gomes R, Figueiredo WS, et al. Concepções de gênero, masculinidade e cuidados em saúde: estudo com profissionais de saúde da atenção primária. Ciênc Saúde Colet [Internet]. 2011 [cited 2016 Feb 7];16(11):4503-12. Available from: http://www.scielo.br/pdf/csc/v16n11/a23v16n11.pdf

4. Gomes R, Rebello LEFS, Nascimento EF, Deslandes SF, Moreira MCN. A atenção básica à saúde do homem sob a ótica do usuário: um estudo qualitativo em três serviços do Rio de Janeiro. Ciênc Saúde Colet [Internet]. 2011 [cited 2016 Feb 7];16(11):4513-21. Available from: http://www.scielo.br/pdf/csc/v16n11/a24v16n11.pdf

5. Silva CSO, Fonseca ADG, Souza LPS, Siqueira LG, Belasco AGS, Barbosa DA. Integralidade e Atenção Primária à Saúde: avaliação sob a ótica dos usuários. Ciênc Saúde Colet [Internet]. 2014 [cited 2016 Feb 8];19(11):4407-15. Available from: http://www. scielosp.org/pdf/csc/v19n11/1413-8123-csc-19-11-4407.pdf

6. Fracolli LA, Gomes MFP, Nabão FRZ, Santos MS, Cappellini VK, Almeida ACC. Instrumentos de avaliação da Atenção Primária à Saúde: revisão de literatura e metassíntese. Ciênc Saúde Colet [Internet]. 2014 [cited 2016 Feb 8];19(12):4851-60. Available from: http://www.scielo.br/pdf/csc/v19n12/pt_1413-8123-csc-19-12-04851.pdf

7. Brasil. Conselho Nacional de Saúde. Resolução 466 de 12 de dezembro de 2012. Dispõe sobre as diretrizes e normas regulamentadoras de pesquisa envolvendo seres humanos. Diário Oficial da União [Internet]. Brasília, p. 59,13 Jun 2013 [cited 2016 Feb 26]. Seção I. Available from: http://conselho.saude.gov.br/resolucoes/2012/Reso466.pdf

8. Callegari-Jacques SM. Bioestatística: princípios e aplicações. Porto Alegre: Artmed; 2003. 264p.

9. Brasil. Ministério da Saúde. Secretaria da Atenção à Saúde, Departamento de Atenção Básica. Manual do Instrumento de Avaliação da Atenção Primária à Saúde: primary care assessment tool PCATool-Brasil. Brasília: Ministério da Saúde; 2010 [cited 2016 Feb 20]. 80p. (MS. Normas e Manuais Técnicos). Available from: http://189.28.128.100/dab/docs/publicacoes/geral/manual_ instrumento avaliacao.pdf

10. Harzheim E, Oliveira MMC, Agostinho MR, Hauser L, Stein AT, Goncalves MR, et al. Validação do instrumento de avaliação da atenção primária à saúde: PCATool-Brasil adultos. Rev Bras Med Fam Comum [Internet]. 2013 [cited 2016 Feb 8];8(29):274-84. Available from: http://www.rbmfc.org.br/rbmfc/article/view/829

11. Silva SA, Baitelo TC, Fracolli LA. Primary Health Care Evaluation: the view of clients and professionals about the Family Health Strategy. Rev Latin-Am Enferm [Internet]. 2015 [cited 2016 Feb 7];23(5):979-87. Available from: http://www.scielo.br/pdf/rlae/ v23n5/pt_0104-1169-rlae-23-05-00979.pdf

12. Carneiro MSM, Melo DMS, Gomes JM, Pinto FJM, Silva MGC. Avaliação do atributo coordenação da Atenção Primária à Saúde: aplicação do PCATool a profissionais e usuários. Saúde Debate [Internet]. 2014 [cited 2016 Feb 8];38(esp):279-95. Available from: http://www.scielo.br/pdf/sdeb/v38nspe/0103-1104-sdeb-38-spe-0279.pdf

13. Silva SA, Fracolli LA. Avaliação da Estratégia Saúde da Família: perspectiva dos usuários em Minas Gerais, Brasil. Saúde Debate [Internet]. 2014 [cited 2016 Feb 7];38(103):692-705. Available from: http://www.scielo.br/pdf/sdeb/v38n103/0103-1104sdeb-38-103-0692.pdf

14. Sala A, Luppi CG, Simões O, Marsiglia RG. Integralidade e Atenção Primária à Saúde: avaliação na perspectiva dos usuários de unidades de saúde do município de São Paulo. Saúde Soc [Internet]. 2011 [cited 2016 Feb 8];20(4):948-60. Available from: http:// www.scielo.br/pdf/sausoc/v20n4/12.pdf

15. Santiago RF, Mendes ACG, Miranda GMD, Duarte PO, Furtado BMASM, Souza WV. Qualidade do atendimento nas Unidades de Saúde da Família no município de Recife: a percepção dos usuários. Ciênc Saúde Colet [Internet]. 2013 [cited 2016 Feb 
6];18(1):35-44. Available from: http://www.scielo.br/pdf/csc/v18n1/05.pdf

16. Jesus MCP, Santos SMR, Lamas JLT, Jesus PBR, Gonçalves PLC, Jory MV. Marcadores de saúde do homem em um município de pequeno porte. Esc Anna Nery Rev Enferm[Internet]. 2014 [cited 2016 Feb 6];18(4):650-5. Available from: http://www.scielo.br/ pdf/ean/v18n4/1414-8145-ean-18-04-0650.pdf

17. Pereira MMM, Cézar ESR, Pereira VCLS, Braga LS, Espínola LL, Azevedo EB. Saúde do homem na atenção básica: análise acerca do perfil e agravos à saúde. Rev Enferm UFPE [Internet]. 2015 [cited 2016 Feb 6];9(Supl. 1):440-7. Available from: http://www. revista.ufpe.br/revistaenfermagem/index.php/revista/article/view/5520

18. Cavalcanti JRD, Ferreira JA, Henriques AHB, Morais GSN, Trigueiro JVS, Torquato IMB. Assistência Integral a Saúde do Homem: necessidades, obstáculos e estratégias de enfrentamento. Esc Anna Nery Rev Enferm [Internet]. 2014 [cited 2016 Feb 5];18(4):62834. Available from: http://www.redalyc.org/pdf/1277/127732789011.pdf

19. Viana LMM. Avaliação da Atenção Primária à Saúde de Teresina na perspectiva das usuárias[Dissertação]. Teresina: Universidade Federal do Piauí; 2012. 127p.

20. Silva FS, Simpson CA, Medeiros KF, Queiroz GR, Silva SYB, Pinheiro MGC. Dificuldades do acesso de trabalhadores na atenção básica de saúde. Rev Enferm UFPE [Internet]. 2013 [cited 2016 Feb 5];7(12):6741-6. Available from: http://www.revista.ufpe.br/ revistaenfermagem/index.php/revista/article/download/4958/7941

21. Vieira KLD, Gomes VLO, Borba MR, Costa CFS. Atendimento da população masculina em Unidade Básica Saúde da Família: motivos para a (não) procura. Esc Anna Nery Rev Enferm [Internet]. 2013 [cited 2016 Feb 8];17(1):120-7. Available from: http:// www.scielo.br/pdf/ean/v17n1/17.pdf

22. Araújo LUA, Gama ZAS, Nascimento FLA, Oliveira HFV, Azevedo WM, Almeida Júnior HJB. Avaliação da qualidade da atenção primária à saúde sob a perspectiva do idoso. Ciênc Saúde Colet[Internet]. 2014 [cited 2016 Feb 8];19(8):3521-32. Available from: http://www.scielo.br/pdf/csc/v19n8/1413-8123-csc-19-08-03521.pdf

23. Lima EFA, Sousa AI, Primo CC, Leite FMC, Lima RCD, Maciel ELN. An assessment of primary care attributes from the perspective of female health care users. Rev Latino-Am Enferm [Internet]. 2015 [cited 2016 Feb 7];23(3):553-9. Available from: http://www. scielo.br/pdf/rlae/2015nahead/pt_0104-1169-rlae-0496-2587.pdf

24. Pereira MJB, Abrahão-Curvo P, Fortuna CM, Coutinho SS, Queluz MC, Campos LVO, et al. Avaliação das características organizacionais e de desempenho de uma unidade de Atenção Básica à Saúde. Rev Gaúch Enferm [Internet]. 2011 [cited 2016 Feb 8];32(1):48-55. Available from: http://www.scielo.br/pdf/rgenf/v32n1/a06v32n1.pdf

25. Araujo JP, Viera CS, Toso BR, Collet N, Nassar PO. Avaliação dos atributos de orientação familiar e comunitária na saúde da criança. Acta Paul Enferm [Internet]. 2014 [cited 2016 Feb 8];27(5):440-6. Available from: http://www.scielo.br/pdf/ape/v27n5/ pt_1982-0194-ape-027-005-0440.pdf

26. Dantas AEA, Santos AEM, Nóbrega JM, Araújo RRG, Oliveira Filho VF, Salomão MAAO. Perfil de homens a partir dos 40 anos atendidos no Programa Saúde do Homem. Rev Ciênc Saúde Nova Esperança [Internet]. 2015 [cited 2016 Feb 20];13(1):21-33. Available from: http://www.facene.com.br/wp-content/uploads/2010/11/Perfil-de-homens-PRONTO.pdf

27. Knauth DR, Couto MT, Figueiredo W dos S. A visão dos profissionais sobre a presença e as demandas dos homens nos serviços de saúde: perspectivas para a análise da implantação da Política Nacional de Atenção Integral à Saúde do Homem. Ciênc Saúde Colet [Internet]. 2012 [cited 2016 Feb 20];17(10):2617-26. Available from: http://www.scielosp.org/pdf/csc/v17n10/11.pdf

28. Gonçalves MR, Harzheim E, Zils ADA, Duncan BB. A qualidade da atenção primária e o manejo do diabetes mellitus. Rev Bras Med Fam Comunidade [Internet]. 2013 [cited 2016 Feb 20];8(29):235-43. Available from: http://rbmfc.org.br/index.php/rbmfc/ article/view/814

29. Leão CDA, Caldeira AP. Avaliação da associação entre qualificação de médicos e enfermeiros em atenção primária em saúde e qualidade da atenção. Ciênc Saúde Colet [Internet]. 2011[cited 2016 Feb 20];16(11):4415-23. Available from: http://www.scielo. $\mathrm{br} / \mathrm{pdf} / \mathrm{csc} / \mathrm{v} 16 \mathrm{n} 11 / \mathrm{a} 14 \mathrm{v} 16 \mathrm{n} 11 . \mathrm{pdf}$

30. Leão CDA, Caldeira AP, Oliveira MMC. Atributos da atenção primária na assistência à saúde da criança: avaliação dos cuidadores. Rev Bras Saúde Matern Infant [Internet]. 2011[cited 2016 Feb 20];11(3):323-34. Available from: http://www.scielo.br/pdf/rbsmi/ v11n3/a13v11n3.pdf

31. Silva SA, Fracolli LA. Evaluating child care in the Family Health Strategy. Rev Bras Enferm [Internet]. 2016 [cited 2016 Feb 28];69(1):54-61. Available from: http://www.scielo.br/pdf/reben/v69n1/en_0034-7167-reben-69-01-0054.pdf 